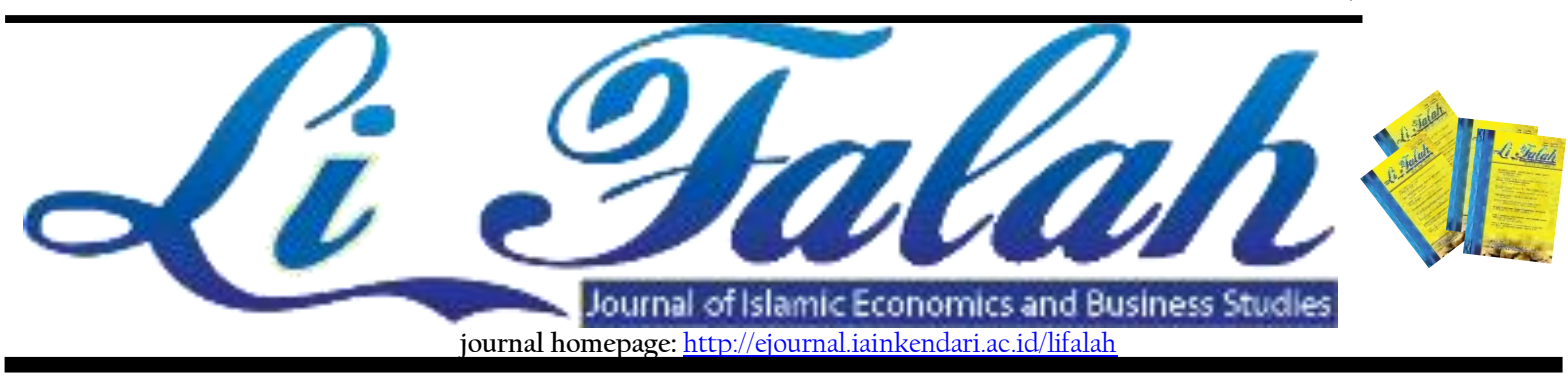

\title{
Product and Service Quality Towards Customer Satisfaction Refilled Drinking Water in Indonesia
}

\author{
Bakhtiar Tijjang1, Nurfadhilah ${ }^{2}$, Pandi Putra ${ }^{3}$ \\ ${ }^{1,3}$ Sekolah Tinggi Ilmu Ekonomi Amsir, Prodi Manajemen, Indonesia \\ ${ }^{2}$ FEBI Institut Agama Islam Negeri Parepare, Indonesia \\ Email: btijiang62@gmail.com ${ }^{1}, \underline{\text { dhila.bakhtiar89@gmail.com }}^{2}$, fandyamsir89@gmail.com $^{3}$
}

\begin{tabular}{l}
\hline \multicolumn{1}{c}{ ARTICLE INFO } \\
\hline Article History: \\
Received October 22, 2020 \\
Received in revised form \\
November 15, 2020 \\
Available online \\
December 31, 2020
\end{tabular}

Keywords:

Product Quality, Service Quality, Customer Satisfaction.

http://dx.doi.org/10.31 332/lifalah.v5i2.2232

\begin{abstract}
A B S T R A C T
The quality of clean water is very crucial needed in human life to meet daily needs. According to the Ministry of Health, drinking water ready for consumption meets tasteless requirements, doesn't smell, is colorless, and contains heavy metals. Although humans can drink water from natural sources, it is risky to be contaminated by bacteria or other invisible harmful substances. The need for clean drinking water, consumable water provides business opportunities, one of them is refill drinking water. This study aims to examine product service quality to consumer satisfaction towards the refill drinking water in Indonesia. The type of research using the explanatory research approach (research explanation) uses a quantitative approach. The population in this study were customers of the refill drinking water in Indonesia whose population was unknown that using Roscoe method to take the sample, which are 50 people with incidental sampling technique. The results showed that product and service quality positively and significantly affect consumer satisfaction partially or simultaneously for customers to refill drinking water in Indonesia.
\end{abstract}




\section{Introduction}

This current competition must be a concern in company activities. Currently, the economy is getting more complicated. There is a lot of competition, including competition in the business world. Many companies are competing to gain market share, so this has pushed the company to continue to move forward in improving its quality. Besides that, with the advancement of technology, companies are also required to keep up with the times, so it isn't outdated.

To grow and develop properly, a company must anticipate increasing competitive economic development by implementing the right strategy to be outdated in competition. Besides, the company must also be able to anticipate future economic trends and must be able to compete with other companies engaged in the same field. To survive and be the progress of the company.

Nowadays, the development of the business world is growing very fast. This fact is indicated by the number of businesses that have developed both in manufacturing and services. In line with the fast growth of the economy, which can create intense competition in the business world because of The development of the business world

The variety of new products that can meet consumer needs that continue to emerge and technological advances is refilling drinking water. Consumers accept this product as an alternative solution to getting the water suitable for consumption. Refill drinking water is growing increasingly, with fair competition in service quality, product quality, price, and promotion.

The quality of clean water is very crucial needed in human life to meet daily needs. According to the Ministry of Health, drinking water ready for consumption meets tasteless requirements, doesn't smell, is colorless, and doesn't contain heavy metals. Although humans can drink water from natural sources, it is risky to be contaminated by bacteria or other invisible harmful substances. The need for clean drinking water, consumable water provides business opportunities, one of them is refill drinking water.

The society that acts as consumers started to be selective and careful in choosing which products to select and consume. Consumers are the key to the success and failure of a business actor in its products' marketing process. Business actors must know the expectations, wants, and needs of consumers without forgetting the quality and paying attention to consumer behaviors in the market. Business actors must also provide more benefits and value than their competitors in distributing their products so that the products they create can exist successfully in the market, compete with competitors, and even win the existing market competition. The goal of a business is to create satisfied consumers. 
Defines customer satisfaction as a person's pleasure or disappointment that comes from comparing his impression of a product's performance and his expectations (Kotler, P. \& Armstrong, 2008). If the performance meets the expectations, the customer will be satisfied, and also if it isn't in line with it. If the implementation does not meet the expectations, the customer will be disappointed. Meanwhile, if the performance exceeds expectations, the customer will be delighted. Customer satisfaction is essential in creating customer trust to use or consume the company's products services.

Satisfied consumers are consumers who receive more value from the company. Satisfying consumers means providing additional products or services, services, or systems used. Customer satisfaction is precious to maintain these customers' existence to keep the business or business effort. Thus, only the company with the best product quality will overgrow, and in the long run, that company will be more successful than others. Therefore, good product quality will lead to consumer satisfaction, where the consumer wants and expectations are met.

Supranto (2001) also stated to measure customer satisfaction. There are several things that business actors need to pay attention to, including employee professionalism and customer responsiveness. Professionalism is the company's performance in providing services to consumers or customers, while service responsiveness shows its concern in responding to customers' complaints. Satisfying consumer needs can increase excellence in business competition. Consumers satisfied with the product or service will tend to repurchase the product and use the service again in the future.

To achieve and create customer satisfaction, business owners must improve the service quality and provide good service to each customer. Good quality service will give the customer satisfaction to feel happy and not disappointed in using the products or services. It will provide high value from consumer perceptions to create customer loyalty with a very long customer satisfaction level.

\section{Research Method}

\subsection{Population and Sample}

In this study, the population is the unknown number of Refill Drinking Water customers in Indonesia. According to Sugiono (2014: 164), sampling using the Roscoe approach in the management research methods book. This study uses multivariate analysis (correlation or multiple regression, for example) so that the number of sample members is at least ten times the number of variables studied. There were three research variables (independent + dependent), so the sample members were at least 30 respondents. Still, the researcher took 50 respondents as the sample under the reasons closer to the truth. The sampling technique used 
is random sampling, namely, determining the model based on chance. Anyone who accidentally meets the researcher at the research location can be used as a sample if it is considered that the person met is suitable as a data source (example).

\subsection{Framework}

The framework is used to facilitate writing or research so that it can provide an overview of the independent variable (X) and the dependent variable (Y) so it will not deviate from the research title, which is the effect of product quality and service quality on consumer satisfaction refill drinking water in Indonesia. The dependent and independent influencing factors are as follows:

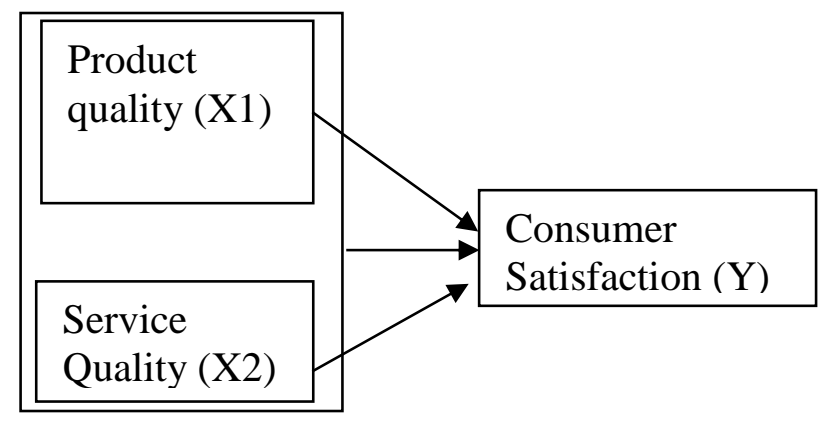

Image 1. Framework

Source: Processed by Researchers (2020)

\section{Result and Discussion}

Validity and reliability tests on raw data were carried out to check each questionnaire's validity and the instruments' consistency. The calculation process is carried out using the SPSS 23 application to obtain accurate calculation results, with the following results:

\subsection{Validity Test}

The validity test is carried out to ensure how well the instrument is used to measure the concept that should be measured. Example: Calculation of the validity using the "product moment" correlation technique obtained by the item correlation coefficient ( $\mathrm{r}$-count) for 15 instrument items (questionnaire) with a sample of 100 people ( $\mathrm{n}=100$ people), with $\alpha=0.05$ obtained $\mathrm{r}$ table 0.195 means that if $\mathrm{r}_{\text {-count }}<\mathrm{r}$-table, then the instrument item is invalid and if $\mathrm{r}$ count $>\mathrm{r}$-table, then the instrument item is valid. The results of statistical calculations for each variable indicate that the $\mathrm{r}^{-}$-count obtained is greater than the $\mathrm{r}$-table, so it is said that all 
questionnaire items are predicated as valid. The values of the correlation coefficients for the validity test of the instrument for each variable are presented as follows:

Table 1. Validity of Product Quality (Xl)

\begin{tabular}{llrrl}
\hline Variabel & Item & r count & r table & Description \\
\hline Product & Statement 1 & 0,602 & 0,273 & Valid \\
quality $\left(\mathrm{X}_{1}\right)$ & Statement 2 & 0,645 & 0,273 & Valid \\
& Statement 3 & 0,684 & 0,273 & Valid \\
& Statement 4 & 0,671 & 0,273 & Valid \\
& Statement 5 & 0,712 & 0,273 & Valid \\
& Statement 6 & 0,634 & 0,273 & Valid \\
& Statement 7 & 0,698 & 0,273 & Valid \\
& Statement 8 & 0,634 & 0,273 & Valid
\end{tabular}

Source: Data processed by SPSS. 23

Based on the table above, it is known that the value of the correlation coefficient for the validity test of the Product Quality variable instrument (Xl) obtained has an average greater than the r table, and all questions are declared valid.

Table 2. The validity of Service Quality (X2)

\begin{tabular}{|c|c|c|c|c|}
\hline Variabel & Item & r count & r table & Description \\
\hline \multirow{5}{*}{$\begin{array}{l}\text { Service } \\
\text { Quality }\left(\mathrm{X}_{2}\right)\end{array}$} & Statement 1 & 0,707 & 0,273 & Valid \\
\hline & Statement 2 & 0,717 & 0,273 & Valid \\
\hline & Statement 3 & 0,702 & 0,273 & Valid \\
\hline & Statement 4 & 0,748 & 0,273 & Valid \\
\hline & Statement 5 & 0,713 & 0,273 & Valid \\
\hline
\end{tabular}

Source: Data processed by SPSS. 23

Based on the table above, it is known that the correlation coefficient value for the validity test of the Service Quality variable instrument (X2) obtained has an average greater than the r table, and all questions are declared valid.

Table 3. The validity of Customer Satisfaction (Y)

\begin{tabular}{llccc}
\hline Variable & Item & r count & r table & Description \\
\hline Customer & Question 1 & 0,601 & 0,273 & Valid \\
Satisfaction & Question 2 & 0,623 & 0,273 & Valid \\
Y) & Question 3 & 0,801 & 0,273 & Valid \\
& Question 4 & 0,631 & 0,273 & Valid \\
& Question 5 & 0,814 & 0,273 & Valid \\
& Question 6 & 0,613 & 0,273 & Valid \\
& Question 7 & 0,765 & 0,273 & Valid \\
& Question 8 & 0,812 & 0,273 & Valid \\
& Question 9 & 0,723 & 0,273 & Valid \\
& Question 10 & 0,787 & 0,273 & Valid \\
\hline
\end{tabular}

Source: Data processed by SPSS. 23 
Based on the table above, it is known that the value of the correlation coefficient for the validity test of the Consumer Satisfaction variable instrument (Y) obtained has an average greater than the $r$-table, and all questions are valid.

\subsection{Reliability Test}

Reliability is the measurement instrument's degree of exactness, precision, or accuracy. A reliability test is intended to see whether a measurement instrument can be trusted (reliable) by performing the variables studied. The reliability measurement was carried using the SPSS.23 statistical test tool, Cronbach's Alpha (a). A constructor variable is reliable if it gives a Cronbach's Alpha value> 0.60 (Ghozali, 2005). Through the results of data processing carried out, the Cronbach's Alpha (a) value is obtained as follows:

Table 4 Reliability of Research Instruments

\begin{tabular}{lll}
\hline No. & Variable & Koefisien Reliabilitas (Alpha) \\
\hline 1 & Product Quality $\left(\mathrm{X}_{1}\right)$ & 0,714 \\
2 & Service Quality $\left(\mathrm{X}_{2}\right)$ & 0,813 \\
3 & Costumer Satisfaction $(\mathrm{Y})$ & 0,879 \\
\hline \multicolumn{2}{l}{ Source: Data processed by SPSS. 23 }
\end{tabular}

The value of the reliability coefficient (Cronbach's Alpha) for each variable shown in table V.5 is greater than 0.60 (criterion value), which means that the measurement instrument used in this study can reveal the variables under study accurately (reliably).

\subsection{Multicollinearity Test}

The multicollinearity test tests whether the regression model found a correlation between independent variables. To detect the presence or absence of multicollinearity in the regression model, if the Tolerance value is more significant than 0.10 and VIF is less than ten, then multicollinearity doesn't occur (Priyatno, 2012). The summary of the multicollinearity test results in this study can be seen in the table below:

Table 5. Multicollinearity Test

\begin{tabular}{llll}
\hline No. & Variable Independent & Tolerance & VIF \\
\hline l. & Product Quality & 0.347 & 2.875 \\
2. & Service Quality & 0.317 & 3.114 \\
\hline
\end{tabular}

Source:: Output SPSS.23

Based on the data presented in table 10, it is known that the Tolerance value of all independent variables is more significant than 0.10 , so it means that there is no correlation 
between the independent variables. Likewise, all the VIF value is less than 10 , and it can be stated that there is no multicollinearity among the independent variables in this study.

\subsection{Multiple Linear Regression Analysis}

Multiple linear regression analysis in this study was conducted to determine how much the influence of the independent variable has on the dependent variable. Based on statistical calculations using SPSS.23, an estimate of the multiple linear regression model is obtained, as shown in the following table:

Table 6. Multiple Linear Analysis

\begin{tabular}{|c|c|c|c|c|c|}
\hline \multirow[b]{2}{*}{ Model } & \multicolumn{2}{|c|}{$\begin{array}{l}\text { Unstandardized } \\
\text { Coefficients }\end{array}$} & \multirow{2}{*}{$\begin{array}{l}\text { Standardized } \\
\text { Coefficients } \\
\text { Beta }\end{array}$} & \multirow[b]{2}{*}{$\mathrm{t}$} & \multirow[b]{2}{*}{ Sig. } \\
\hline & $\mathrm{B}$ & Std. Error & & & \\
\hline $1 \quad$ (Constant) & 1,780 & ,675 & & 1,214 &, 320 \\
\hline $\begin{array}{l}\mathrm{X}_{1} \text { Product } \\
\text { Quality }\end{array}$ & ,814 & ,127, & 220 & 2,086 & ,028 \\
\hline $\begin{array}{l}\mathrm{X}_{2} \text { Service } \\
\text { Quality }\end{array}$ & ,739 & , 070 & , 162 & 11,447 & ,008 \\
\hline & & & & & \\
\hline
\end{tabular}

Dependent Variable: Customer Satisfaction

Source: Primary data processed, 2020

The coefficient table above informs the regression equation model obtained from the constant-coefficient and the variable coefficient. From the data that has been presented, a regression equation model is formed as follows:

$$
\begin{aligned}
& Y=a+b_{1} X_{1}+b_{2} X_{2}+b_{3} X_{3}+b_{4} X_{4} \\
& Y=1,780+0,814 X_{1}+0.739 X_{2}
\end{aligned}
$$

The brackets represent each independent variable's significant value where the regression coefficient $<\alpha(0.05)$ means a significant effect. Variable Product Quality (Xl), Service Quality (X2), the value is positive, which explains that the relationship is in line with Customer Satisfaction (Y). If the independent variables increase, then the value of the dependent variable will also increase or contrariwise. Meanwhile, the intercept value and the coefficient value of each variable Product Quality (X1), Service Quality (X2), Customer Satisfaction (Y) in the equation above can be described as follows: 
1) Intercept 1,780 states that there is no Product Attribute Product Quality (Xl), Service Quality (X2). Consumer Satisfaction is 1,780 units.

2) Product Quality (Xl): 0.814 means that if the Product Quality variable increases by 1 unit, it will increase Customer Satisfaction by 0.814 units.

3) Service Quality (X2): 0.739 means that if the Service Quality variable increases by 1 unit, it will increase Customer Satisfaction by 0.739 units.

\subsection{Analysis of the Coefficient of Determination (R2)}

The coefficient of determination (R2) is a measure that shows how far the independent variable can explain the variation in the dependent variable. The value of the coefficient of determination can be determined by looking at the Adjusted R-Square value in the output. Through data processing carried out using the SPSS.23 program, the following result is obtained:

Table 7. Test $\mathrm{R}^{2}$

\begin{tabular}{|c|c|c|c|c|}
\hline \multicolumn{5}{|c|}{ Model Summary } \\
\hline Model & $\mathrm{R}$ & R Square & $\begin{array}{l}\text { Adjusted R } \\
\text { Square }\end{array}$ & $\begin{array}{l}\text { Std. Error of the } \\
\text { Estimate }\end{array}$ \\
\hline 1 & $.921^{a}$ & ,848 & 807 & ,704 \\
\hline \multicolumn{5}{|c|}{ a. Predictors: (Constant), $X_{2}, X_{1}$} \\
\hline b. Depe & t Variable: & & & \\
\hline
\end{tabular}

The coefficient determination determines the independent variable's contribution to the dependent variable. After calculating the SPSS.23 application, the coefficient of determination (r-square) is 0.848 . This value can be defined as $84.8 \%$ of the Consumer Satisfaction variable can be explained by Product Quality and Service Quality. The remaining $15.2 \%$ is influenced by other variables included in this study.

\subsection{Hypothesis test}

Testing is carried out on each hypothesis in the following steps:

a. The t-test for Variable Product Quality

The $t$-test for bl is carried out to test the first hypothesis, namely:

Ho: presumably, there is no effect of Product Quality on Consumer Satisfaction refill drinking water in Indonesia

Hl: It is suspected that Product Quality's effect on Consumer Satisfaction refills drinking water in No. 
If the sign value $<0.05$, then $\mathrm{H}_{1}$ is accepted, or by comparing $\mathrm{t}_{\text {-count }}>\mathrm{t}$-table, the decision is $\mathrm{Hl}$ that accepted.

Table 8. Output t-test for product quality variables

\begin{tabular}{|c|c|c|c|c|c|c|}
\hline \multicolumn{7}{|c|}{ Coefficients } \\
\hline \multirow{2}{*}{\multicolumn{2}{|c|}{ Model }} & \multicolumn{2}{|c|}{$\begin{array}{l}\text { Unstandardized } \\
\text { Coefficients }\end{array}$} & \multirow{2}{*}{$\begin{array}{l}\text { Standardized } \\
\text { Coefficients } \\
\text { Beta }\end{array}$} & \multirow[b]{2}{*}{$t$} & \multirow[b]{2}{*}{ Sig. } \\
\hline & & $\mathrm{B}$ & Std. Error & & & \\
\hline \multirow[t]{2}{*}{1} & (Constant) & 1,780 &, 675 & & 1,214 & ,320 \\
\hline & $\begin{array}{l}\mathrm{X}_{\mathrm{l}} \text { Kualitas } \\
\text { Produk }\end{array}$ & ,814 & ,127 & ,220 & 2,086 & ,028 \\
\hline
\end{tabular}

Dependent Variable: Customer Satisfaction

Source: Primary data processed, 2020

Based on the table above, the regression equation $\mathrm{Y}=1,780+0.814 \mathrm{Xl}$ is obtained. This equation explains that every 1 unit increase in Product Quality will increase the Purchase Decision by 0.814 units. Based on the calculation results, the $t$-count value is 2.086 , while the $t$ table with 48 degrees of freedom at $\alpha(0.05)$ is 2.01l. Thus $t$-count (2.086) $t$-table (2.011), so it's clear that $\mathrm{HO}$ is rejected and $\mathrm{Hl}$ is accepted, or based on the results of calculation and data processing, a signed value of 0.028 is obtained.

b. The t-test for Service Quality Variables

The $t$-test for $b_{2}$ was carried out to test the second hypothesis, which are:

$\mathrm{H}_{\mathrm{o}}$ : presumably, there is No. effect of product quality on the refill drinking water in Indonesia. $\mathrm{H}_{2}$ : It is assumed that there is an effect of product quality in the refill drinking water in Indonesia

If the sign value $<0.05$, then $\mathrm{Hl}$ is accepted, or by comparing $t$-count $>t$-table, the decision is $\mathrm{H}_{2}$ accepted.

Table 9. Output-test for service quality variables

\begin{tabular}{|c|c|c|c|c|c|c|}
\hline \multirow{2}{*}{\multicolumn{2}{|c|}{ Model }} & \multicolumn{2}{|c|}{ Unstandardized Coefficients } & \multirow{2}{*}{$\begin{array}{l}\text { Standardized } \\
\text { Coefficients } \\
\text { Beta }\end{array}$} & \multirow[b]{2}{*}{$t$} & \multirow[b]{2}{*}{ Sig. } \\
\hline & & $\mathrm{B}$ & Std. Error & & & \\
\hline \multirow[t]{2}{*}{1} & (Constant) & 1,780 & ,675 & & 1,214 & ,320 \\
\hline & $\begin{array}{l}\overline{\mathrm{X}_{2} \text { Kualitas }} \\
\text { Pelayanan }\end{array}$ &, 739 & ,070 & ,162 & 11,447 & ,008 \\
\hline
\end{tabular}

Dependent Variable: Customer Satisfaction

Source: Primary data processed, 2020

Based on the table above, it is obtained the regression equation $\mathrm{Y}=1.780+0.739 \mathrm{X} 2$. This equation explains that every increase of 1 unit of service quality will increase customer satisfaction by 0.739 units. Based on the calculation results, the $t$-count value is 11.447 while the 
$t$-table with 48 degrees of freedom at $\alpha$ (0.05) is 2.011. Thus $t$-count (1l.447) $>t$-table (2.011), so it is clear that $\mathrm{H}_{\mathrm{o}}$ is rejected and $\mathrm{H}_{2}$ is accepted, or based on the calculation and data processing results, the sign value is 0.008 . Thus the decision is clear that $\mathrm{H}_{\mathrm{o}}$ is rejected and $\mathrm{H}_{2}$ is accepted.

\section{c. Simultaneous Significance Test (Test F)}

The $\mathrm{F}$ test is carried out to test the first hypothesis, which are:

$\mathrm{H}_{\mathrm{o}}$ : it is assumed that there isn't the effect of Product Quality and Service Quality together on customer Satisfaction Refill drinking water in Indonesia

$\mathrm{H}_{3}$ : it is assumed that there is the effect of Product Quality and Service Quality together on Consumer Satisfaction Refill drinking water in Indonesia

If the sign value $<0.05$, then the decision $\mathrm{H}_{1} \mathrm{~s}$ accepted, or by comparing $\mathrm{F}_{\text {count }}>\mathrm{F}_{\text {-table, the }}$ decision is $\mathrm{H}_{3}$ accepted.

Table 10. Output Test F

\begin{tabular}{|c|c|c|c|c|c|c|}
\hline Model & & Sum of Squares & df & Mean Square & $\mathrm{F}$ & Sig. \\
\hline \multirow[t]{3}{*}{1} & Regression & 148,051 & 5 & 29,612 & 56,406 & $.000^{\mathrm{b}}$ \\
\hline & Residual & 28,863 & 63 &, 753 & & \\
\hline & Total & 187,913 & 65 & & & \\
\hline a. Depe & Variable: Y & & & & & \\
\hline
\end{tabular}

After calculating using the SPSS.23 program, the value of F-count 56.406 is obtained, shown in table 10. While the critical value of $\mathrm{F}$-table value with degrees of freedom of numerator two and denominator 47 at $\alpha(0.05)$ is 3.20. Thus $F_{\text {-count }}(56.406)>F_{\text {-table }}$ (3.20), so it is clear that $\mathrm{Ho}$ is rejected and $\mathrm{H}_{3}$ is accepted when comparing the sign value of 0.000 . This finding shows that the variable product quality and service quality significantly affect customer satisfaction refilling drinking water in Indonesia.

\section{Conclusions}

Based on the results of research and discussion of the effect of Product Quality and Service Quality on Consumer Satisfaction refill drinking water in Indonesia, the conclusions of this study below are:

1. There is a significant effect of Product Quality on Consumer Satisfaction in refilling drinking water In Indonesia. Based on the calculation results, the $t$-count value is 2.086, while the $t$-table with 48 degrees of freedom at $\alpha(0.05)$ is 0.273 . Thus $t$-count $(2.086)>t$-table $(2.011)$, so it is clear that $\mathrm{H}_{\mathrm{o}}$ is rejected and $\mathrm{H}_{1}$ is accepted or based on the results of calculation and 
data processing, a signed value of 0.028 is obtained. Thus the decision is clear that $H_{o}$ is rejected and $\mathrm{Hl}$ is accepted.

2. There is a significant influence of the Service Quality variable on Customer Satisfaction refilling drinking water in Indonesia. From the calculation results, the $t$-count value is 11.447, while the $t$-table with 48 degrees of freedom at $\alpha(0.05)$ is 0.273 . Thus $t$-count (11.447)> $t$-table (2.011), so it is clear that $\mathrm{H}_{\mathrm{o}}$ is rejected and $\mathrm{H}_{1}$ is accepted, or based on the results of calculation and data processing, a signed value of 0.008 is obtained. Therefore the decision is clear that $\mathrm{H}_{\mathrm{o}}$ is rejected and $\mathrm{H}_{2}$ is accepted.

3. There is a significant effect of Service Quality and Product Satisfaction variables in refilling drinking water in Indonesia. Based on the calculation results, it is obtained that F-count (56.406) $>\mathrm{F}_{\text {-table }}$ (3.20), so it is clear that $\mathrm{H}_{\mathrm{o}}$ is rejected and $\mathrm{H}_{3}$ is accepted as well when comparing the sign value of 0.000 . 


\section{References}

A. Parasuraman, Valarie A. Zeithaml, and Leonard L. Berry. 1988. "SERVQUAL: A MultipleItem Scale for Measuring Consumer Perceptions of Service Quality." Journal of Retailing. Vol 64 (1) pp 12-37

Agnanda, F dan Farida, N. (2012). Pengaruh Nilai Pelanggan, Kesadaran Merek dan Switching Barrier Terhadap Loyalitas Pelanggan Kartu Telkom Flexi. Jurnal Ilmu Administrasi Bisnis, hal.1-8.

Arikunto, S. (2010). Prosedur Penelitian Suatu Pendekatan Praktik. Jakarta: Rineka Cipta.

Flaherty, K., Mowen, J., Brown, T., \& Marshall, G. (2008). Leadership propensity and sales performance among sales personnel and managers in a specialty retail store. Journal of Personal Selling and Sales Management. https://doi.org/10.2753/PSS0885-3134290103

Griffin, Ricky,W. dan Ronald J.Ebert. (2011). Bisnis. Terjemahan. Jakarta: Erlangga.

Hadiati, Sri, dan Sarwi Ruci (1999). "Analisis Kinerja Kualitas Pelayanan Terhadap Kepuasan.," Jurnal Manajemen dan Kewirausahaan, Vol. 1, No. l.

Heizer, Jay dan Render, Barry. (2005). Operations Management, Edisi Ketujuh, diterjemahkan oleh Dwianoegrahwati Setyoningsih, M.Eng.Sc dan Indra Almahdy, M.Sc. Penerbit Salemba Empat. Jakarta.

Kotler dan Keller. 2009. Manajemen Pemasaran. Jilid I. Edisi ke 13. Jakarta: Erlangga.

Kotler, Phillip. 1996. Manajemen Pemasaran: Maketing Management. Jakarta: PT. Prenhallindo.

Kotler, P. \& Armstrong, G. (2008). Prinsip-Prinsip Pemasaran. Edisi 12. Jilid 1. Manajemen Pemasaran

Kotler, P., \& Keller, K. L. (2012). Principles Of Marketing Kotler 14th Edition Pearson. In Pearson Education Limited, Essex, England.

Kotler, Philip. (2011). Reinventing Marketing to Manage. Journal of Marketing.

Robbins, P. Stephen, Mary Coulter. 2014. Management. Twelfth Edition.United States: Pearson Education Limited.

Sugiyono. (2015). Memahami Penelitian Kualitatif. Bandung: Alfabeta.

Supranto. (2001). Pengukuran Tingkat Kepuasan Pelanggan Untuk Menaikkan Pangsa Pasar. Jakarta, Rineka Cipta.

Tjiptono, F. (2014). Pemasaran Jasa - Prinsip, Penerapan, dan Penelitiab. In 1.

Yamit, Zulian. (2003). Manajemen Persediaan. Yogyakarta: EKONISIA.

Yamit, Zulian. (2001), Manajemen Kualitas Produk dan Jasa, Y ogyakarta: Ekonosia 